\title{
The co-production of difference? Exploring urban youths' negotiations of identity in meeting with difficult heritage of human classification
}

\author{
Kaja Hannedatter Sontum
}

Department of Archaeology, Conservation and History, University of Oslo, Oslo, Norway

This paper explores the capacity of museums to stimulate critical reflection and dialogue on constructions of human difference relating to the past, and thereby to serve as agents of social change. The study draws on material from focus groups with youths, aged 16-18, following their visit to the exhibition FOLK - from racial types to DNA sequences at the Norwegian Museum of Science and Technology in Oslo. By juxtaposing past and present ideas and research on human biological variation, and its political and social ramifications, the exhibition aims to provoke consciousness and debate on strategies of establishing Us and Them. Discourse analysis demonstrates the negotiations involved in audience meaning-making, but also indicate the transforming potential of engagement with difficult heritage. The interactions and discussions between the visitors themselves emerge as an important ingredient in what constitute this potential. Museums are, however, in the position to become arenas for such deep discussion.

Keywords: audience research; difficult heritage; difference; identity; discourse

\section{Introduction}

One of the central questions for a human being is 'who am I?' Another question that people focus on is 'who are you?' You have the need to categorize yourself and others (Hannah, 2018).

The opening statement is from of a discussion between Hannah $^{1}$ and her upper-secondary school classmates, ${ }^{2}$ following their visit to the exhibition FOLK - from racial types to DNA sequences at the Norwegian Museum of Science and Technology. By juxtaposing interwar 'race science' and contemporary research on population genetics, the museum project seeks to inspire critical reflection on ideas and discourses of human sameness and difference. On her part, Hannah notes how people frequently and habitually experience themselves and others as being persons of various kinds. Among the diverse array of tactics that people adopt 
to make sense of their world, the formation of Self and Other is a pivotal and influential strategy, not least because "identities are constructed through, not outside difference" (Hall, 1996, p. 15). While Peggy Levitt (2015, p. 2) asks if museums can inspire a greater openness and respect for difference, whether it be next door or across the world, human difference is never finally defined. Rather, it is continuously and interactionally produced, and established as effective social categories.

This paper explores the potential for museums to serve as locations for the navigation of perennial questions of identity and belonging, by stimulating engagement with difficult heritage of human classification. The study investigates meaning as emerging in the meeting between the FOLK exhibition and four groups of young visitors. The relevance of developing arenas for such engagement is accentuated by the increasing global mobility and connectivity of our time, and by the recent surge of commercial DNA testing, appealing to a kind of 'genetic essentialism' with possible effects on narratives of selfhood relating to the past (see e.g. Lawton and Foeman, 2017; Nordgren and Juengst, 2009). While such effects have been explored elsewhere, this paper examines social outcomes when museums purposefully aim to present difference and identity as fluid and constructed. To what extent do contemporary urban youths accommodate, ignore, negotiate or resist such representations?

Addressing this key question, the study draws on material from recorded and transcribed focus groups with youths living in the Greater Oslo Region, one of the fastest growing urban areas in Europe. The paper proceeds in three analytical steps. Firstly, curatorial aims are examined based on articulations by members of the museum project group and internal interpretative documents. Secondly, the content of the exhibition and learning program is elucidated through observations of the youths' visits. Finally, in the main stage of analysis, audience meaning-making is explored by combining concepts from discourse 
psychology with the method of qualitative coding. The results emphasize the variability and unpredictability in visitors' interactions with museum messages, but also indicate the transforming potential of critical heritage engagement.

\section{Museums and human difference}

Literature and practice of recent years have confirmed that museums are not, and cannot be, apolitical, objective or 'neutral' spaces (Mason, 2013, p. 59; Sandell, 2007, p. 195). In other words, "it is naïve to deny the agency of the museum or the inevitability of a partisan bearing” (Whitehead, Mason, Eckersley, \& Lloyd, 2015, p. 50). Through representation, museums construct social and political orders and values. As public institutions assigned both to safeguard and define culture, they have long since been thoroughly positioned as sites for the constitution and negotiation of difference (Sherman, 2008, p. 2). There has been a growing interest, however, in their capacity to subvert dominant representations, foster inclusive identities, combat prejudice, and facilitate understanding (Lloyd, 2014, p. 148; Sandell, 2007, pp. 3-4). To what extent, and how, museums take on such societal roles vary. Furthermore, while many institutions aim to extend beyond bounded categories of heritage and identity, the place-based lenses through which the world is seen frequently mean that ideas of territorial, homogenous collectives are sustained (Ang, 2017, p. 4), rather than the deconstruction of static and simplified conceptions of Us and Them.

In Norway, like in most comparable nation-states world-wide, demographic changes have induced a search for more inclusive museum policies and practices, emphasizing an agenda of diversity. Recent initiatives relate to issues of low minority recruitment, and strategic documents suggest dialogue, cooperation and re-programming to more relevant content. ${ }^{3}$ Politically, this has been a question of integration and representation. However, topdown approaches continue to be anchored in a traditional identity paradigm. The underlying 
assumption is that if programs are made relevant for Them, by presenting Their minority cultures and histories, the minority audience will turn up. Existing surveys on practices and attitudes of "diverse museum useres" provide little support for this notion (Gran and Vaagen, 2010, p. 7; Norsk Folkemuseum and Oslo Museum, 2011). On the contrary, several younger respondents seem frustrated with being pigeon-holed into socio-ethnic stereotypes (Prescott, 2019, pp. 60-61). Current strategies risk to further alienate those feeling 'somewhere inbetween' and unable to fully belong within the ascribed normative categories (Sontum, forthcoming; Sontum and Fredriksen, 2018, p. 416). More important in this context, however, is the limited attention that has been given to exploring the possible social outcomes of alternative representational forms.

\section{Audience meaning-making}

This study focuses primarily on processes of audience reception. That is, on the ways in which visitors respond to and interact with an exhibition that, by presenting difficult heritage of human classification, intends to stimulate critical reflection and dialogue on constructions of difference. Difficult heritage is here defined as a past that is recognized as meaningful in the present, but that is also awkward for public reconciliation with a positive, self-affirming contemporary identity (Macdonald, 2009, p. 1). There has long been a reluctance to acknowledge such potentially identity-disrupting pasts. This, however, is changing, with a turn towards more frequent public addressing of unsettling histories (Macdonald, 2015, p. 6; Witcomb, 2013, p. 255). The research participants are seen as active agents in the construction of meaning. Aged 16-18, they are at a particular time in their lives, when it is common to ask: 'who am I', 'where do I fit in', 'what will I be?' Their narrations of social location are produced in interplay with the available stories told around them, as they draw on various identification models and interpretative repertoires as flexible discursive resources (Anthias, 2002, p. 499; Wetherell and Potter, 1992, pp. 89-90). The study explores how the 
youths make use of such resources in creating and negotiating representations of Self and Other, and the degree to which the specific museum encounter rouses critical consciousness and alternative positions. In the following, the aims of the exhibition producers are presented, before proceeding to the main analysis.

\section{Curatorial aims}

The FOLK exhibition is produced by the National Medical Museum, part of the Norwegian Museum of Science and Technology (NMST). Its introductory panel asserts how "race has a long history as scientific concept and research topic". While the heyday of scientific racism is over, underlying ideas are prevalent. As further elaborated in internal project statements, the aim is to enable visitors to explore, understand and discuss some of the origins of these ideas, and how they continue to affect people's lives. The intention is not to separate or narrate "in a linear way that proceeds from bad racial science to a race-free and unproblematic contemporary science" (NMST, 2018), but rather to juxtapose past and present research on human biological variation. The exhibition relates to the rapid developments in genome research, with focus on population genetics and origins, and an increasing attention among the general public towards questions of ancestry, roots, and identity. ${ }^{4}$ By providing a historical context, the project group wants "to help lay the foundation for critical debate on this development" (NMST, 2017). The concept of 'meeting' is central, as are questions of how we define people as belonging to Us or as being the Other. The title, FOLK, directly points to the main theme:

\footnotetext{
It carries with it the simple observation that people are similar and different in many ways. It also points to the possibility of constructing specific human groups based on perceived common characteristics. As our vantage point is scientific research, the word FOLK brings in the cultural aspects of identity formation and belonging. Finally, FOLK reminds us of the historical connections of such research with ethno-racial nationalism and its emphasis on pure national communities based on blood and cultural bounds (NMST, 2018).
} 
Torhild Skåtun (2018), the museum educator responsible for developing the learning program for visiting school classes, acknowledges that these issues are highly complex. The exhibition is an "attempt to unpack some aspects". Historian of science Ageliki Lefkaditou (2018), one of the two lead curators, elaborates:

\footnotetext{
We have these physical characteristics, which make us look different from one another, but actually we are the most boring species on the planet, in terms of biological variation. I don't believe that we should try to force people to think that we are all the same, it's a good thing that we are not, that we are all different: but what does this mean, really, and in which ways are we different, and what are the consequences of the similarity or the difference? That is what makes this discussion interesting.
}

Further, she expresses her hope that visitors will leave with an understanding of how 'race' is not a valid biological concept, and emphasizes problematic connections between ideas of race and ethnicity:
Although the concept of ethnicity was initially developed to refer to more cultural aspects, biology and culture are not so easily differentiated. Both in the past and today, ethnicity is intertwined with ideas of biology, and as the years have gone by, and race has lost its legitimacy, biological features that were incorporated in the concept have shifted to the idea of ethnicity (Lefkaditou, 2018).

Both members of the project group reject the idea of museums as value-neutral institutions of objective knowledge. Lefkaditou (2018) asserts that people who adopt such a view "fail to realize that they are in a position of power; that everything you do as a public institution, in one way or the other, affects the ways people perceive things. The museum is political, in every aspect". However, "this does not mean that curators, or museum institutions, necessarily should promote a specific ideological agenda, or should enforce their views on visitors". Rather than to present any final conclusions, Lefkaditou (2018) stresses, museums should evoke curiosity: "Our stories are curated through our own perspectives, but I hope that they allow space for people to think for themselves". 


\section{Developing and conducting focus groups}

Seeking to explore the extent and ways in which a young audience actually enters into dialog with the museum messages, the process of recruiting focus group participants was initiated by sending out invitations to all upper secondary schools within the Greater Oslo Region. Efforts were made to engage schools with different profiles, especially in terms of geographical location within the city. The final sample consisted of two school classes, one from East End and one from West End Oslo. As a conceptual boundary and image of division, East and West End is more debated and has a stronger hold on inhabitant's minds than any other representation of the city that refers to cultural, economic and political differences. While such representations may have basis in detectable patterns, ${ }^{5}$ they also function as strong symbols of what East End and West End are, as places and as indicators for the identity of the people who live there.

After their visits to the exhibition, in October and November 2018, the youths were divided into smaller groups of 10-12 participants. In the four individual focus group settings, they were encouraged to interact and discuss freely; to ask each other questions, exchange anecdotes and comment on each other's understandings and points of view (see Kitzinger and Barbour, 1999, p. 4). A list of 13 open-ended questions was developed, aiming to generate and capture conversations stimulated by the museum encounter. The exhibition was used as a point of departure for exploring ideas of difference relating to concepts of ancestry and origin, and the questions can be divided into three overall themes (Table 1).

The first section aimed to examine level of interest in personal DNA testing, and understandings of what one could learn from taking such a test. Following participants' accounts of collective pasts as connected to fixed categories of belonging in the present, probes were made into what they recognize as their own history, and what this means in 
terms of their self-identification. This was followed by questions concerning ideas of ethnicity and race, relating to definitions of 'ethnic Norwegian'. The youths were asked how they feel this distinction is commonly defined, if the definition reflects their personal perspectives, and if it offers them a sense of connection. The final section generated discussions on the concept of culture. As will be further deliberated, conversations conveyed an interpretative repertoire of continuous change, and perceptions of difference as a social process.

Table 1. Themes for discussion as related to exhibition messages

\begin{tabular}{|l|l|}
\hline Ideas presented in the exhibition & Themes for discussion in focus groups \\
\hline $\begin{array}{l}\text { Contemporary knowledge on human genetics; } \\
\text { issues and uncertainties; complex human history } \\
\text { of continuous mobility and migration }\end{array}$ & $\begin{array}{l}\text { Genetic testing and ancestry; collective pasts; } \\
\text { significance for self-identification }\end{array}$ \\
\hline $\begin{array}{l}\text { Past and present constructions of race and } \\
\text { ethnicity; from essentialist properties to social } \\
\text { processes }\end{array}$ & $\begin{array}{l}\text { Definitions of 'ethnic Norwegian'; sense of } \\
\text { connection }\end{array}$ \\
\hline $\begin{array}{l}\text { Relationships with (internal and external) } \\
\text { cultural identification }\end{array}$ & What is culture; how is cultural difference and \\
\end{tabular}

The use of pre-existing groups meant that established social dynamics were included as an aspect of the study (see Munday, 2006, p. 97), and were seen as playing an important role in the co-construction and negotiation of meaning. The implementation of an approach that opened up for the youths influencing the agenda made it possible to directly witness this construction, as they examined their own views and the views of others in the group (see Liamputtong, 2011, p. 18). Shared frames of understanding surfaced, but also points of disagreement and uncertainty. 
In the subsequent systematic analysis, qualitative coding was applied as a method of classifying and reorganizing (Saldaña, 2014, p. 584). The transcriptions were read and reread in order to decipher the core meaning of passages, and similarly coded data were grouped into themes. Contradictory stories or utterances were not seen as threats to the reliability of the study, but rather as signs of variation in language use and the application of different interpretative repertoires (Sandell, 2007, p. 18; Wetherell and Potter, 1992, pp. 101-102). In the following sections, analytical claims are connected with examples in the material. First, however, the content of the exhibition and learning program is presented based on observations of the youths' visits.

\section{The exhibition and learning program}

Before entering the exhibition, the participants are shown a camera used by physical anthropologists in the 1920s (Figure 1). The museum educator talks about the object, and how it reflects the theme of the exhibition: historic and contemporary practices of "people studying people”. Moving into the exhibition space, they begin their tour by watching two short movies. With simple animations, these videos present nineteenth century scientists' efforts to make systematic sense of human variation. The idea of biological race, as objective and naturally occurring divisions, became a way of classifying humanity by physical appearances, geography and cultural traits. Further, the movies visualize today's knowledge on human genetics, stressing how we are, as a species, extremely similar. All human beings are 99,9 per cent identical in their genetic makeup. Homo sapiens emerged in Africa about 300000 years ago, and dispersed to the rest of the world. Recent genome research suggests that we only have to go back 4000 years to find a common ancestor for all contemporary people on earth. It is emphasized that our history is complex, and has been forged by movements, encounters and migrations: we all have multiple origins. Differences in our appearances are the result of mutations and variations in world environments, in terms of 
climate and amount of sunlight. Today, our increasing mobility is disrupting geographical variations that used to exist.

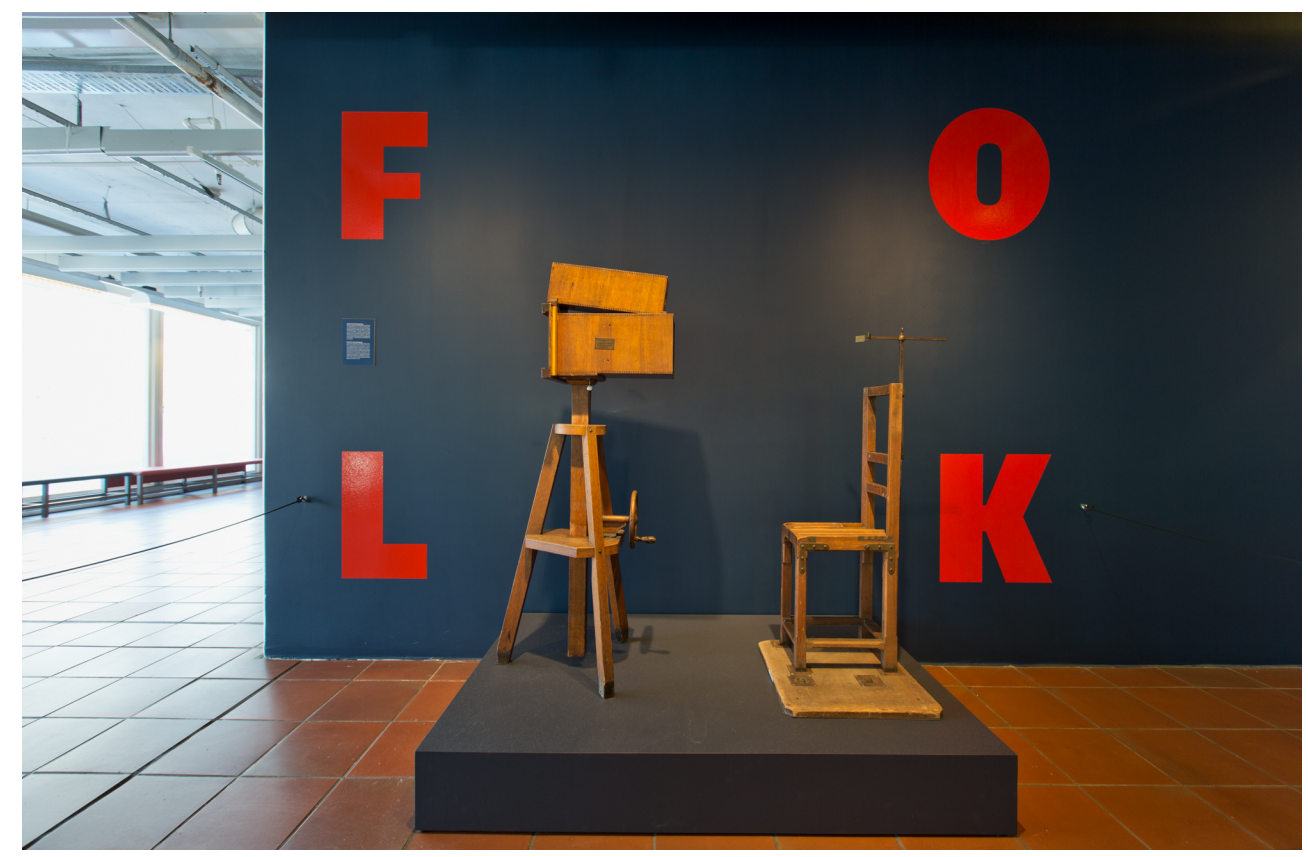

Figure 1. Camera used in the 1920s, at the entrance to the FOLK exhibition. Image origin: Håkon Bergseth/NMST.

After watching these videos, the youths are invited to examine one of the three exhibited human skulls. The museum educator explains that the scull is from a Viking Age woman, previously interpreted as being of the 'Nordic type'. Recently, samples taken from her teeth have revealed a lineage rare in areas of today's Europe, but common in the Black Sea Region. The participants are shown a reconstruction of her face. ${ }^{6}$ Such reconstructions, while based on contemporary knowledge on genetics, involve interpretations and assumptions. The youths move towards a round structure that is entitled the cabinet of curiosities (Figure 2). With its 'window displays' in different sizes, the structure references early efforts of understanding the world and human diversity. With their version, the project group wants visitors to reflect on the ways in which people and cultures have been stereotyped, valuated and classified. The cabinet contains both historic and contemporary artifacts, including a direct-to-consumer DNA testing kit. The museum educator talks about companies offering 
personalized reports, promising to uncover the ethnic and geographic origins of one's ancestors. While commercial genetic testing builds on contemporary research, methods and results are obscure and speculative. Inside the cabinet, short movies display two personal narratives about uncovering family history and reclaiming a Sami identity in the aftermaths of Norwegianization policies, which were discontinued in the 1980 s. $^{7}$

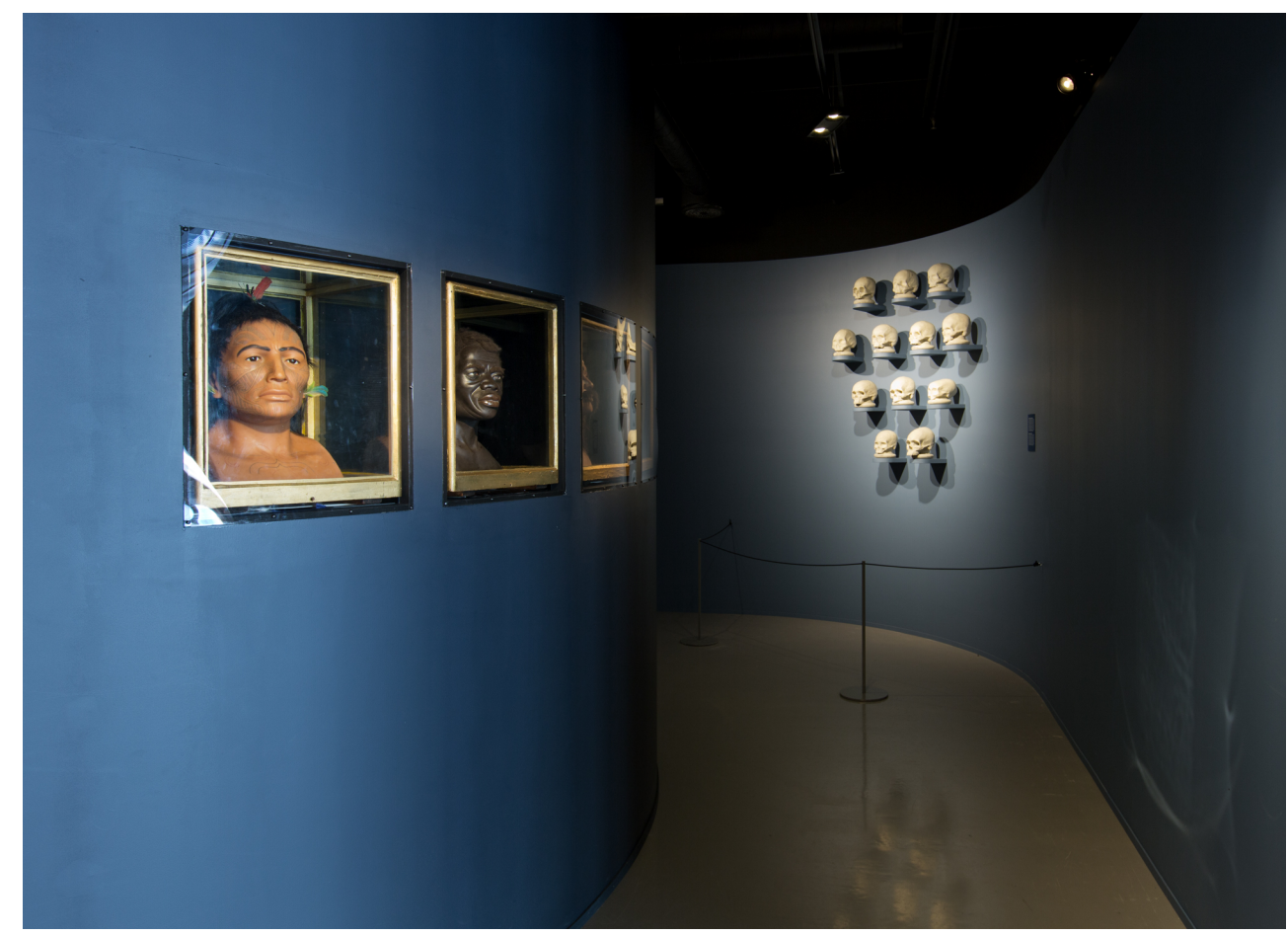

Figure 2. Part of the cabinet of curiosities, with waxworks commonly found in nineteenth century European museums. In the background are casts of sculls used by phrenologists in the beginning of the same century. Image origin: Håkon Bergseth/NMST.

Moving beyond the cabinet, the youths are told how a second structure in the center of the room is meant to illustrate an archive, and displays objects related to data creation, classification and systematization (Figure 3). This archive represents science as an attempt to bring rationality to the world through specific but changing methods and practices. On one side of the structure, they are shown a wall display of military recruit photos, taken in connection with a major 'race survey' of the country in the 1920s (Figure 4). 


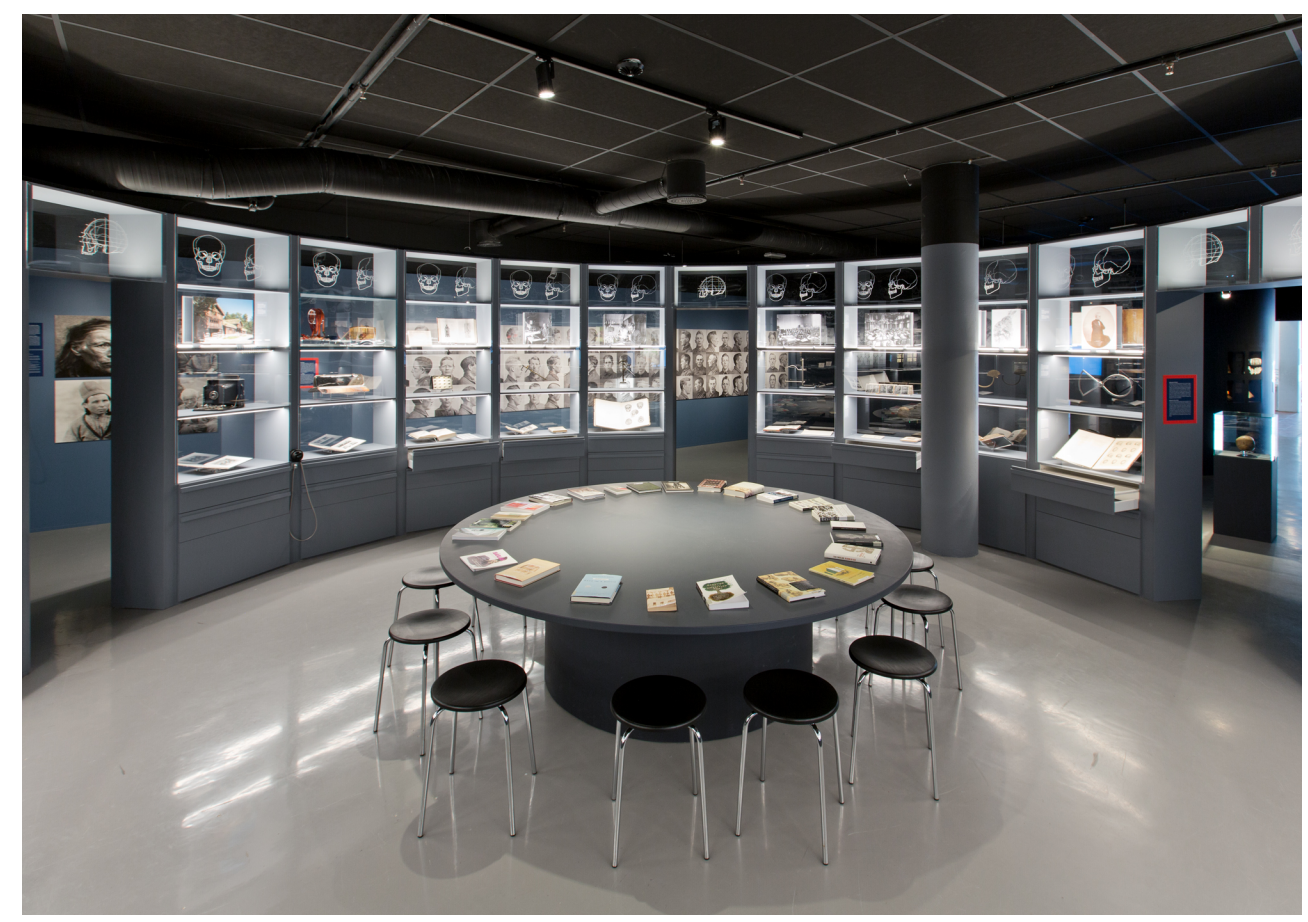

Figure 3. The archive is developed to facilitate dialog-oriented activities. Image origin: Håkon Bergseth/NMST

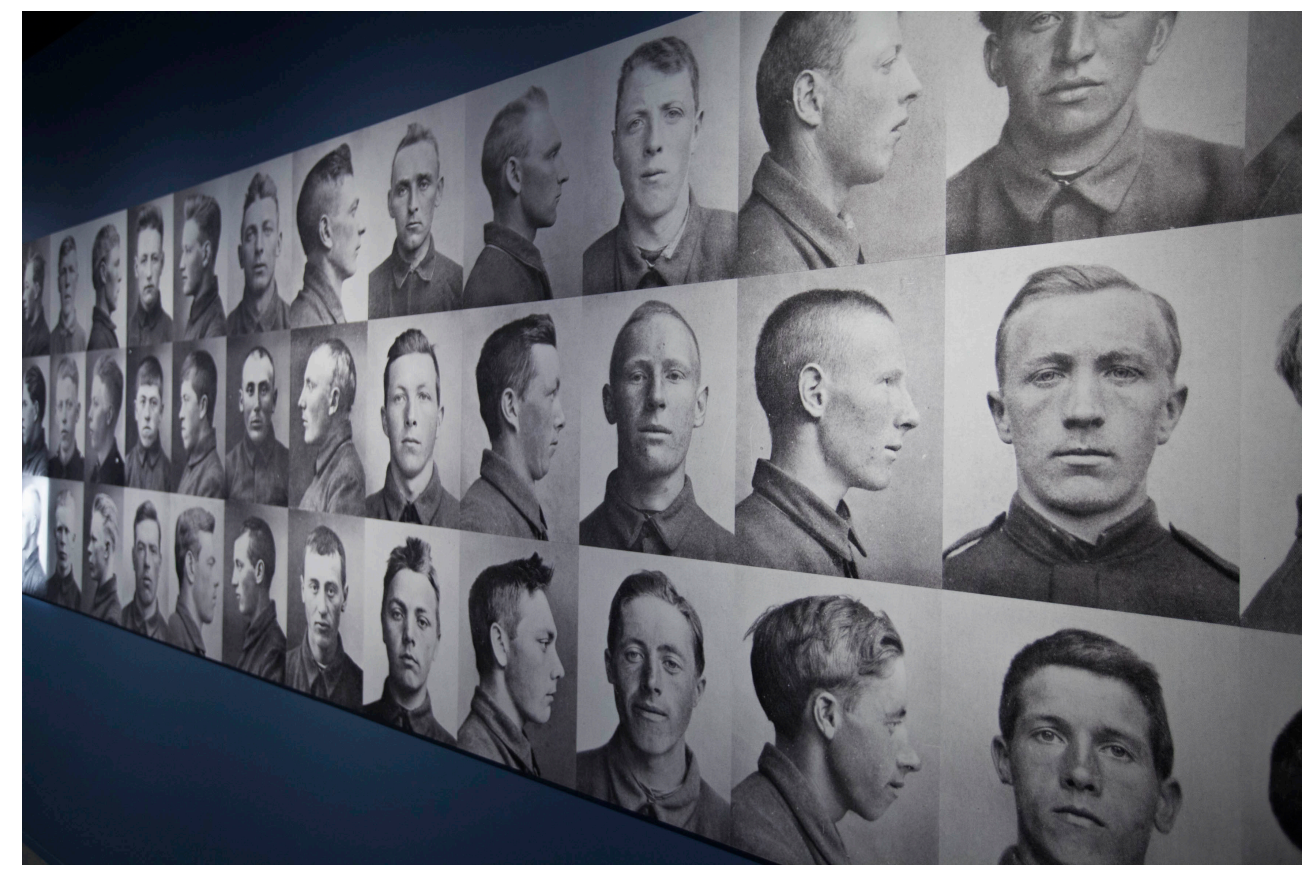

Figure 4. Small part of the massive collection of recruit photos from the 1920s. Image origin: Håkon Bergseth/NMS

In addition to the survey, detailed studies were conducted on populations in the small towns of Setesdal and Tysfjord. While Tysfjord was chosen because of the Sámi population,

Setesdal was selected as representing a community of a purebred 'Nordic' racial type. The 
youths are shown photographs of individuals from the study alongside video monitors displaying responses by their descendants, emphasizing how the experience affected the community in Tysfjord and how it lives on in the memories of people there today.

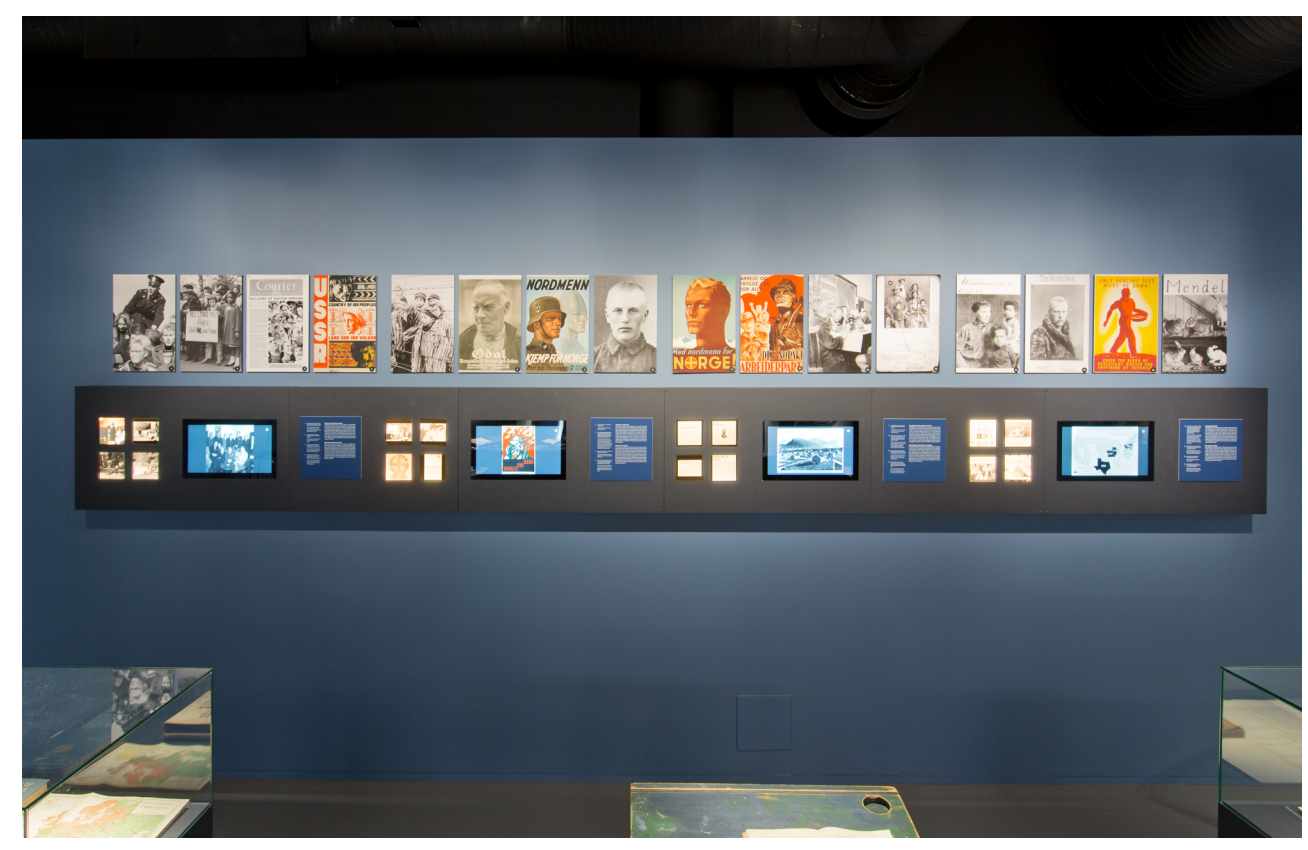

Figure 5. The political uses and abuses of science are made explicit. Touchscreens allow visitors to read more about related topics. Image origin: Håkon Bergseth/NMST

Moving on, the museum educator talks about how eugenics and research on 'racial' differences were instrumental in nationalist projects aiming to 'improve' the qualities of populations. Posters, photographs and interactive touchscreens present relationships between physical anthropological research, the Norwegian and international racial hygiene movement, and Nazism in Norway and Germany (Figure 5). This section also includes counterclaims and resistance to eugenics within Norwegian and international anti-racism initiatives, most prevalent after WWII. Today, there is near complete scientific consensus that race has no meaning as a biological concept. However, it continues to exist as a powerful social construct - ostensibly abandoned ideas live on. 


\section{Negotiating ancestry as interpretative repertoire of identity}

While the transcriptions of the subsequent focus groups display great variation, in terms of interactional dynamics and accounts of personal experiences, patterns also emerge showing shared interpretative repertoires. The youths' discussions on commercial DNA testing demonstrate the coexistence of two frames for meaning-making. First, they draw on a representation of inherited belonging, connecting concepts of distinct collective pasts and origins to ideas of contemporary group membership and identity. Aisha expresses how results from genetic testing might influence her to learn more about the history of a specific geographical area, to which she sees herself as connected through ancestry: "If I, for example, were told that I have some blood from Algeria, I would have started looking things up and learning more about that country. It's something I would tell my children”. In one group, participants note how findings might challenge one's self-understanding: "I think it's better to know only what I know. If I learned something new, then I would have to start all over" (Sareena). In the subsequent discussion, however, Lanya applies an alternative interpretative framework. This can be described as a perspective of practice, choice and continuous change, relating to lived experiences and manifested in deconstructions of static categories:

\footnotetext{
Sareena: Okay, for example, if you think you're from the Middle East, but you're actually from, I don't know, the other side of that. Someone might be quite proud of where they come from, right, but then they hear that they're not really from there.
}

Lanya: But you can still say that you're Lebanese, even if you find out (..)

\footnotetext{
Sareena: No, I can't do that. If I suddenly find out that I'm from Australia, I can't say that I'm from the Middle East.
}

Lanya: Yes, actually, because it's not you who are from Australia, it's your ancestors. It's up to the individual. I feel that identity, where you come from, it's where you feel you're from (...) Actually, I don't think that a piece of paper has anything to do with it. It's the culture, in a way, what you do in practice, in your life, that's what determines where you're from. 
Sareena: But the paper does affect you. No matter what you feel you are, no matter what you do, the paper will ultimately affect you. You can sit there saying 'I feel like that, I do things like this', but in the end, when you look at the paper, it says who you are.

This conversation illustrates tensions between the two models of identification. There is no sense, however, in dividing the youths into groups, each distinguished by a different underlying 'attitude' or belief. Rather, the interpretative repertoires form part of constant negotiations of Self. They are nevertheless discernible, based on inconsistencies between the different forms of account. Similar moments of negotiation emerge when the youths were asked about how they would define their own history. Many articulate stories of descent: "The Ottoman Empire. You know, I'm half Turkish and half Bulgarian, but my Turkish roots are from the Ottomans, because they occupied Bulgaria back then, right, and I'm a descendant from those Turks" (Daniela). Zahra notes how people frequently abide to a single national narrative:

It's like, when we have social studies, and suddenly it's something about Pakistan, all Pakistanis will be interested in hearing about that. And if it's about Palestine, we're going to be interested in reading about that. We feel it's our history, while the Norwegians have their history.

Several participants express a wish to teach their future children about their historical roots, as defined by their parents' place of birth, but also that they would expect and accept changes in perspectives: "I'm going to tell them about it, I think it's important, but it's up to them if they want to take care of their history or not" (Daniela). In terms of the distinction "ethnic Norwegian', all accounts relate to parentage: "Ethnic Norwegian is a term used about people who have parents and grandparents that are born in Norway" (Leah). When asked if their children will be ethnic Norwegians, however, several of the youths who present their family history as one of migration express doubts. Sareena relates this uncertainty to external identification based on physical appearance, thus connecting phenotype to ideas of ethnicity: 
If they put it in their heads that they're Norwegian, then yes, they could say that. But if you go out now and ask a random person, one who is ethnic Norwegian, if you ask that person: 'look at me, am I ethnic Norwegian?', then you know what kind of answer you'll get. Even if you say 'I'm Norwegian, I'm ethnic Norwegian', the way you look won't show that you are.

However, she later stresses how formations of difference based on perceptions of origin and ancestry may change over time:

Today, it's kind of like; these are the ones with minority background, these are in the ethnic Norwegian group. But if we look at Australia, if we think historically, then the Australians are not the original people, they came from Europe. But after a long period of time, they've become, sort of, the Australians.

Thus, while several of the youths initially apply a perspective of bounded categories of inherited belonging, their following discussions convey recognitions of difference as a process. Such a perspective is also displayed in Lanya's contestation of 'Norwegianness' as defined by a localized collective past:

The divide is really about what they believe: they believe they're Norwegian, that they've always been here (...) But in the past, the boundaries didn't exist as they do today, like 'this is Norway, this is Sweden', those boundaries didn't exist. So, we can't really say that 'we're from this country', because it only became a country later, it wasn't in the past.

Participants in all four groups commonly present categorization as a learned practice. As expressed by Emma: "it's very much society around us that makes us categorize". Many emphasize how we all make use of classifying representations, and connect such strategies to people's efforts of navigating and constituting their world. "People categorize because they need to feel in control" (Emma). They "feel safer when they can place people in boxes" (Oliver). However, while the youths' conversations reveal their understandings of such processes as intrinsic to social life and human experience, they also emphasize tensions between the two qualities of identification - between the internally defined and the externally ascribed. 


\section{Difference as experienced social processes}

Such tensions are also manifested in the participants' discussions on cultural difference.

Culture is commonly presented as ways of doing, including ways of dressing, cooking, talking, and socializing. Practices are discursively connected to categorized groups, yet also presented as facilitating re-invention and transformation through interaction and meetings:

"Culture is formed all the time. If we take the Pakistanis, or the Kurds, they change our food culture, for example, by bringing in new types of food" (Adrian). "We have to relate to their culture, because it enters our culture in a way; it's becoming part of our culture" (Charlotte). Participants from migrant families express a sense of 'mixing' cultures, on an individual level, thus challenging either-or models. Lanya asserts that "it's becoming a mix; in the way that I am and the way that I think". Similarly, Malika's account depicts a process of creating something new, through active selection: "We take the best from each, and we mix them together". However, several youths also convey experiences of being 'in-between' categories:

If I go back to Somalia, I don't know if I'm going to feel a hundred percent Somali. Because those who live there might think that 'she's a foreigner'. They sort of have a different view on you. And when you're here in Norway, you don't feel a hundred percent Norwegian. Sometimes I think: 'where do I come from?' Can I call myself a hundred percent Somali? Can I call myself a hundred percent Norwegian? (Caaliyah).

While Caaliyah expresses the difficulty of positioning herself in accordance with a binary social ontology, Sareena refers to a sense of being excluded from specific practices, such as wearing a traditional costume, bunad, on the Norwegian constitution day. Thereby, she draws attention to the externally defined negotiability of her belonging:

There will always be someone who says no. They're going to say that 'you're not like us'. But I can discuss that, really. Because both me and that person are probably born here, and we've gone through the same things, although we may not look like each other.

The participants frequently articulate a sense of division, or segregation, within their home 
city: "Those with money live in the West End, and it's the Norwegians who live there, the ethnic Norwegians. People in the East End have lower income, and a different background than Norwegian" (Naima). When placing themselves in relation to this 'divide', the youths simultaneously establish the Other, as exemplified by Anna's comment: "You see it on the people who live around there. Maybe it's because they want to feel belonging too, that they want to be around people they feel are more the same as them, who have the same culture as them". Meanwhile, many express a sense of alienation relating to external ascription of Otherness: "They just put you in a category because you live there, or because you look like them" (Sada). Classifying descriptions of the social landscape are, however, often nuanced in following discussions, frequently initiated by contesting remarks. In these instances, negotiations of meaning relate to variations in practice: "I'm not trying to say that all Norwegians are West End boys or West End girls. But you see it in the way they behave, their style, the way they talk; it's things you notice" (Sareena). Processes of identification and differentiation are obviously 'made known' to the youths in a number of different settings. Their conversations convey reflexive engagement with the ideas and underlying 'logics' of such processes, but also reveal how their meaning-making is framed by their everyday life experiences.

\section{Between curatorial aims and lived experiences}

The results and excerpts of discussions demonstrate how concepts of ancestry and discrete, collective pasts are inherent to identification models the participants draw on in making sense of their world, and their place in the social order of things. Their initial representations, through which ideas of genetic ancestry are connected with contemporary geographies of belonging, suggest that the capacity of museums to reframe difference, and thereby to serve as agents of social change, might not necessarily translate into practice. Katherine Lloyd (2015, p. 149) notes that the denaturalization of essentialist categories by museums may lead 
to a sense of destabilization, a phenomenon that can result in discomfort, retrenchment or defensive responses amongst visitors. While institutions may strive to represent the fluid nature of identity, within individuals' daily lives the desire to hold fixed understandings stems from the need for stability and coherence. Alternative perspectives may be rejected in meeting with an existing sense of Self.

Significantly, however, the youths' conversations also reveal critical reflections, processes of negotiation, as well as movement between positions involving different interpretative repertoires. Relating to the aims of the museum producers, their talk-ininteraction reverberates what Richard Sandell (2007, pp. 98-100) identifies as a dynamic and dialogic interpretation. Their responses are neither entirely accepting of, nor resistant to, ideas presented in the exhibition. In terms of messages of the 'dangers' of hierarchical classification, this is acknowledged, but also negotiated based on experiences from their own social navigations. As expressed by Hannah, "no matter where you go, no matter what group you're a member of, no matter what community you're looking at, there are always signs of hierarchy". The youths' oral exchanges, I argue, convey what can be termed a constructionist recognition of difference, but also emphasize the reality of its social consequences.

This becomes more evident in their articulations on culture, which commonly display a perspective of continuous change. For the youths from migrant families, classifying descriptions of bounded entities serve as resources for creating new, hybrid spaces for their doing and becoming (see also Sontum, forthcoming). However, accounts also convey tensions between internally and externally defined belongings. In such instances, the stability of their more naturalized identifications, which is expressed in statements such as 'I am a...' and defined in terms of descent and origin, is related to it being a source of identity ascription from others. The findings reflect the interactional character of interpretative processes that 
can occur in a museum setting, revealing the interplay between perceived messages and lived experiences. While few of the youths explicitly express changes in perspectives, the analysis demonstrates how the exhibition encounter functions as a catalyst for critical engagement.

\section{Concluding remarks}

The introductory questions of this paper concerned the potential for museums to serve as arenas for the navigation of perennial questions of identity and belonging, by presenting unsettling histories of human classification and its political and social ramifications. The discussions and negotiations between the young visitors to the FOLK exhibition highlight the relevance of developing such arenas, and of current efforts to extend beyond traditional categories of 'diversity', but also emerge as an important ingredient in what constitute this potential. While the exhibition serves as a starting point for exploration, the participants turn the dialogic agenda towards associations and experiences from their daily lives. Museums are, however, in the position to become locations for such deep reflection and discussion, and thereby to serve as co-creators of new social possibilities, and alternative stories about what it means to belong.

\section{Notes}

${ }^{1}$ All names referenced in this paper are fictional and used to facilitate reading.

${ }^{2}$ The original statement is: "En av de store spørsmålene hos et menneske er 'hvem er jeg?' En annen tanke som mennesker har er 'hvem er $d u$ ? Du har jo behov for å kategorisere deg selv og andre". All translations from Norwegian in this article are by the author.

${ }^{3}$ Such strategies have been initiated by the National Network for Minorities and Cultural Diversity (Nettverk for minoriteter og kulturelt mangfold). Initiatives also include Norwegian Parliament's declaration of 2008 as the Year of Cultural Diversity (Mangfoldsåret), and the marking of the European Year of Cultural Heritage in 2018, with the slogan Typical Norwegian - not just Norwegian (Typisk norsk - ikke bare norsk).

${ }^{4}$ Since the turn of the millennium, at least 12 million people worldwide have paid for DNA tests, hoping to uncover their own genetic secrets. Norwegians are among the most eager users (Christiansen, 2019). 
${ }^{5}$ According to Oslo City Statistics' (2018), the "immigrant population" constitutes 33,1 per cent of the city's inhabitants. Over a quarter of these are "Norwegian-born to immigrant parents". The immigrant population is over-represented in several East End city districts (Oslo City Statistics, 2018; Statistics Norway, 2015). Based on numbers form 2011, Terje Wessel (2017, p. 99) observes that especially one variable affects representation in the West End districts: level of education. Recent research also reveals economic and health related patterns of segregation (Elstad, 2017; Wiborg, 2017), and demonstrates a lingering orientation amongst East End residents towards the political left, and towards the political right in the West End (Bjørklund, 2017).

${ }^{6}$ The reconstructions in the exhibition are developed by Face Lab at Liverpool John Moores University.

${ }^{7}$ My family portrait (2013), directed by Yvonne Thomassen, and Suddenly Sami (2009), directed by Ellen-Astri Lundby. A compilation film is also displayed, with scenes from Tomorrow's children (1934), directed by Crane Wilbur, and Surviving Eugenics (2015), directed by Jordan Miller, Nicola Fairbrother and Robert A. Wilson.

\section{Notes on contributor}

Kaja Hannedatter Sontum is currently $(2016$ - 2019) a $\mathrm{PhD}$ candidate in archaeology at the Department of Archaeology, Conservation and History, University of Oslo (UiO). She graduated from UiO with an MA in archaeology and critical heritage studies in 2015. This work brought her to the University of Cambridge as an exchange student in 2014. She has participated in several archaeological excavations and heritage management projects, most recently at the Museum of Cultural History, UiO. Her doctoral research explores consequences of increasing global mobility and connectivity for constructions and uses of heritage in discourses of identity and belonging.

\section{References}

Ang, I. (2017). What are museums for? The enduring friction between nationalism and cosmopolitanism. Identities, 24(1), pp. 1-5. doi:10.1080/1070289X.2016.1260019

Anthias, F. (2002). Where do I belong? Narrating collective identity and translocational positionality. Ethnicities, 2(4), pp. 491-514.

Bjørklund, T. (2017). Topartisystemet forsvant, men øst-vest-skillet bestod. In J. Ljunggren (Ed.), Oslo: ulikhetenes by (pp. 145-169). Oslo: Cappelen Damm Akademisk. 
Christiansen, H. (2019). Jakten på jeget [The hunt for the self]. A-magasinet, Aftenposten. Retrieved 8 February 2019.

Elstad, J. I. (2017). Helseulikhetenes by. In J. Ljunggren (Ed.), Oslo: ulikhetenes by (pp. 171187). Oslo: Cappelen Damm Akademisk.

Gran, A., \& Vaagen, H. (2010). Kunnskap om - medvirkning av - formidling for mangfoldige museumsbrukere [Knowledge of - and involvement in - dissemination for diverse museum users]. Retrieved 8 February 2019 from https://docplayer.me/3118243-Kunnskap-om-medvirkning-av-formidling-formangfoldige-museumsbrukere.html.

Hall, S. (1996). Introduction: Who Needs 'Identity'? In S. Hall \& P. du Gay (Eds.), Questions of cultural identity (pp. 1-17). London: Sage.

Hannah. (2018, October 25). Focus group led by K. H. Sontum [Digital recording, fictional name to maintain confidentiality]. FOLK exhibition. NMST, Oslo

Kitzinger, J., \& Barbour, R. S. (1999). Introduction: The Challenge and Promise of Focus Groups. In R. S. Barbour \& J. Kitzinger (Eds.), Developing Focus Group Research: Politics, Theory and Practice (pp. 1-20). London: Sage.

Lawton, B., \& Foeman, A. (2017). Shifting Winds: Using Ancestry DNA to Explore Multiracial Individuals' Patterns of Articulating Racial Identity. Identity, 17(2), pp. 69-83. doi:10.1080/15283488.2017.1303383

Lefkaditou, A. (2018, January 23). Interview by K. H. Sontum [Digital recording]. FOLK exhibition. NMST, Oslo.

Levitt, P. (2015). Artifacts and Allegiances: How Museums Put the Nation and the World on Display Oakland: University of California Press.

Liamputtong, P. (2011). Focus Group Methodology: Principles and Practice London: Sage.

Lloyd, K. (2014). Beyond the rhetoric of an "inclusive national identity": Understanding the potential impact of Scottish museums on public attitudes to issues of identity, citizenship and belonging in an age of migrations. Cultural Trends, 23(3), pp. 148158. doi:10.1080/09548963.2014.925279

Lloyd, K. (2015). Negontiating Place, Heitage and Diversity: Young People's Narratives of Belonging and Exclusion in Scotland. In C. Whitehead (Ed.), Museums, migration and identity in Europe: People, Places and Identities (pp. 149-182). Farnham: Ashgate.

Macdonald, S. (2009). Difficult heritage: Negotiating the Nazi past in Nuremberg and beyond Abingdon: Routledge.

Macdonald, S. (2015). Is 'Difficult Heritage' Still 'Difficult'? Museum International, 67(14), pp. 6-22. doi:10.1111/muse. 12078 
Mason, R. (2013). National museums, globalization, and postnationalism: imagining a cosmopolitan museology. Museum Worlds, 6(1), pp. 40-64. doi:10.3167/armw.2013.010104

Munday, J. (2006). Identity in focus: The use of focus groups to study the construction of collective identity. Sociology, 40(1), pp. 89-105. doi:10.1177/0038038506058436

NMST. (2017). FOLK: project description. Unpublished internal document.

NMST. (2018). FOLK: an interpretation. Unpublished internal document.

Nordgren, A., \& Juengst, E. T. (2009). Can genomics tell me who I am? Essentialistic rhetoric in direct-to-consumer DNA testing. New Genetics and Society, 28(2), pp. 157-172. doi:10.1080/14636770902901595

Norsk Folkemuseum, \& Oslo Museum. (2011). Innvandreres bruk av museum - En undersøkelse [Immigrants' use of museums - A survey]. Retrieved 8 February 2019 from $\quad$ https://docplayer.me/8031648-Innvandreres-bruk-av-museer-enundersokelse.html.

Oslo City Statistics. (2018). Befolkningens landbakgrunn. Retrieved 8 February 2019 from https://www.oslo.kommune.no/politikk-ogadministrasjon/statistikk/befolkning/landbakgrunn/\#gref.

Prescott, C. (2019). Changing demographics and cultural heritage in Northern Europe: transforming narratives and identifying obstacles - a case study from Oslo, Norway. In C. Holtorf, A. Pantazatos \& G. Scarre (Eds.), Cultural Heritage, Ethics and Contemporary Migrations (pp. 52-69). London: Routledge.

Saldaña, J. (2014). Coding and Analysis Strategies. In P. Leavy (Ed.), Oxford Handbook of Qualitative Research (pp. 581-605). Cary: Oxford University Press.

Sandell, R. (2007). Museums, prejudice and the reframing of difference London: Routledge.

Sherman, D. J. (2008). Introduction. In D. J. Sherman (Ed.), Museums and difference (Vol. 2, pp. 1-21). Bloomington: Indiana University Press.

Skåtun, T. (2018, January 4). Interview by K. H. Sontum [Digital recording]. Folk exhibition. NMST, Oslo.

Sontum, K. H. (forthcoming). Defining 'heritage communities' in an age of migrations. Urban youths' narratives of translocality Building Heritage Communities: Empowering the Local Routledge.

Sontum, K. H., \& Fredriksen, P. D. (2018). When The Past is slipping. Value tensions and responses by heritage management to demographic changes: a case study from Oslo, Norway. International Journal of Heritage Studies, 24(4), pp. 406-420. doi:10.1080/13527258.2017.1378907

Statistics Norway. (2015). Innvandrere på Oslo-kartet. Retrieved 8 February 2019 from https://www.ssb.no/befolkning/artikler-og-publikasjoner/innvandrere-pa-oslo-kartet. 
Wessel, T. (2017). Det todelte Oslo - etniske minoriteter i øst og vest. In J. Ljunggren (Ed.), Oslo: ulikhetenes by (pp. 81-104). Oslo: Cappelen Damm Akademisk.

Wetherell, M., \& Potter, J. (1992). Mapping the Language of Racism: Discourse and the Legitimation of Exploitation New York: Harvester Wheatsheaf.

Whitehead, C., Mason, R., Eckersley, S., \& Lloyd, K. (2015). Place, Identity and Migration and European Museums. In C. Whitehead, K. Lloyd, S. Eckersley \& R. Mason (Eds.), Museums, Migration and Identity in Europe: People, Places and Identities (pp. 7-59). Farnham: Ashgate.

Wiborg, Ø. N. (2017). Hvor er formuene i Oslo? Gylne ghettoer og deres utvikling over tid. In J. Ljunggren (Ed.), Oslo: ulikhetenes by (pp. 105-120). Oslo: Cappelen Damm Akademisk.

Witcomb, A. (2013). Understanding the role of affect in producing a critical pedagogy for history museums. Museum Management and Curatorship, 28(3), pp. 255-271. doi:10.1080/09647775.2013.807998 